УДК 539.196,3

\title{
THE H-BOND AND NEAR SURFACE LAYER STRUCTURE IN BICOMPONENT HETEROSYSTEMS ON THE BASIS OF TITANIUM DIOXIDE NANO PARTICLES
}

\author{
LM. Babkov, T.V. Bezrodna*, G.A. Puchkovska*, \\ K.E. Uspenskiy, V.V. Shimanovska* \\ Saratov State University \\ E-mail: babkov@sgu.ru \\ *Institute of Physics, NAS of Ukraine, Kiev \\ E-mail: puchkov@iop.kiev.ua
}

Regarding the IR spectra of the solid samples of titanium dioxidebenzophenone and titanium dioxide-4-amil-4'-cyanobiphenyl heterogenic bicomponent mixtures measured at room temperature the presence of hydrogen bonds in the samples was revealed. The titanium dioxide compound was represented as nano crystalline particles embedded into corresponding sample. Using density functional theory method $(B 3 L Y P / 6-31+G(d))$ the modeling of the structures and vibrational spectra of the bezophenone, 4-amil-4'-cyanobiphenyl and water free molecules, followed by the modeling of the structures and spectra of the $\mathrm{H}$-bond complexes which are formed in near surface layers of the titanium dioxide nano crystalline particles due to water, which is adsorbed on their surfaces had carried out. On the basis of analysis of the bands spectroscopic parameters (the location, intensity and shape) in IR spectra (measured and simulated) corresponded to hydroxyl, carbonyl and cyano group bonds stretches, the theoretical ground of the titanium dioxide nano crystalline particles near surface layers forming in heterogenic bicomponent systems was given. It is found that the basic role in this mechanism plays the hydrogen bond.

Водородная связь и структура приповерхностных слоев в двухкомпонентных гетеросистемах на основе наночастиц диоксида титана

Л.М. Бабков, Т.В. Безродная, Г.А. Пучковская, К.Е. Успенский, В.В. Шимановская

На основе анализа ИК спектров твердых образцов гетерогенных двухкомпонентных смесей бензофенон-диоксид титана и 4-амил4'цианобифенил-диоксид титана, измеренных при комнатной температуре было обнаружено наличие в образцах водородных связей. С использованием метода теории функционала плотности (B3LYP/6-31+G(d)) было проведено моделирование структур и колебательных спектров свободных молекул бензофенона, 4-амил-4'-цианобифенила и воды, их Н-комплексов, образующихся в приповерхностных слоях наночастиц диоксида титана при участии воды, адсорбирующейся на их поверхностях. На основе анализа спектроскопических параметров полос (положения, интенсивности и формы) в измеренных и рассчитанных ИК спектрах, соответствующих колебаниям связей карбонильной группы, гидроксильной группы и цианогруппы, были даны теоретические выводы о формировании приповерхностных слоев наночастиц диоксида титана в гетерогенных двухкомпонентных системах. Установлено, что основную роль в механизме их образования играет водородная связь.

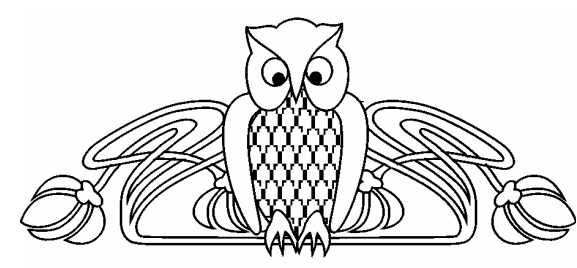

\section{INTRODUCTION}

The experimental investigation of the bicomponent heterogenic nano systems on the basis of titanium dioxide $\left(\mathrm{TiO}_{2}\right)$ had performed in the works [1-3] using spectroscopic methods. One of the basic results obtained in those investigations is regarded to the structure of the near surface layers of the $\mathrm{TiO}_{2}$ nano crystalline particles and to the intermolecular interactions inside the layer. On the ground of the analysis of the measured IR spectra $[2,3]$ the authors making a conclusion that the basic mechanism of intermolecular interactions in these systems is the hydrogen bond. It is forming due to water which is always on the surface of titanium dioxide because of its strong hygroscopic property. The water is changing the structure of the $\mathrm{TiO}_{2}$ nano crystalline particles surface: it is hydroxylated. As a result, the conditions for the different $\mathrm{H}$ bond complexes formation in near surface layers of $\mathrm{TiO}_{2}$ nano crystalline particles are created, including $\mathrm{H}$-bond complexes of water with $\mathrm{TiO}_{2}$, and water with the adsorbed organic polar molecules, particularly benzophenone (BP) and 4-amyl-4'-cyanobiphenyl (5CB), which are playing role of the probe. Regarding to the changes in their IR spectra in the regions of $\mathrm{O}$ $\mathrm{H}, \mathrm{C}=\mathrm{O}$ and $\mathrm{C} \equiv \mathrm{N}$ bonds stretches appearance it is possible to make a conclusions about the presence of hydrogen bond and about its influence on the near surface layer structure formation.

The aim of this work is the theoretical proof of the structure forming role of H-bond in near surface layers of $\mathrm{TiO}_{2}$ nano crystalline particles in $\mathrm{BP}-\mathrm{TiO}_{2}$ and $5 \mathrm{CB}-\mathrm{TiO}_{2}$ bicomponent 
mixtures on the basis of molecular modeling using density functional method(B3LYP) [4] realized in Gaussian'03 software (for Windows).

For this purpose the structure dynamical models for water $\left(\mathrm{H}_{2} \mathrm{O}\right)$, BP and 5CB free molecules were created. Structure dynamical models

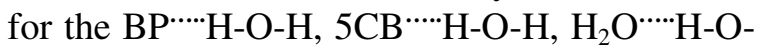
$\mathrm{Ti} \equiv, \mathrm{BP}^{\cdots \cdots} \mathrm{H}-\mathrm{O}-\mathrm{Ti} \equiv$, and $5 \mathrm{CB}^{\cdots \cdots} \mathrm{H}-\mathrm{O}-\mathrm{Ti} \equiv \mathrm{H}-$ bond complexes which supposed to be formed in the near surface layer of $\mathrm{TiO}_{2}$ nano crystalline particles in considered bicomponent heterogenic mixtures were also created. Vibrational spectra from [3] was used .The technology of the samples preparing is given in the same work too.

\section{MOLECULAR MODELING}

Using density functional method (B3LYP) and $6-31+\mathrm{G}(\mathrm{d})$ basis set the structural dynamical models of the objects mentioned above were created.

The energies of these molecular systems models were minimized and a full optimization of their geometric parameters was performed. Their electro-optical parameters were calculated and IR spectra were computed in harmonic approximation. At the modeling of the $\mathrm{H}_{2} \mathrm{O} \cdots \cdot \mathrm{H}-\mathrm{O}-\mathrm{Ti} \equiv$,

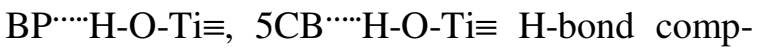
lexes three remaining free valences of the titanium were filled by hydroxyl groups. The structure dynamical model of the titanium hydroxide $\mathrm{Ti}(\mathrm{OH})_{4}$ were created as auxiliary model. The calculated frequencies were scaled using method [5].

The hydrogen bond energy were estimated using empiric Iogansen formula $\Delta H=-0.3(\Delta v-$ $-40)^{1 / 2}[6]$, where $\Delta v$ is the shift of the stretching vibration $\mathrm{O}-\mathrm{H}$ when the $\mathrm{H}$-complex formed ( $\Delta \mathrm{H}$ is given in $\mathrm{kkal} / \mathrm{mol}$ and $\Delta \mathrm{v}$ is given in $\mathrm{cm}^{-}$ $\left.{ }^{1}\right)$.

\section{RESULTS AND DISCUSSION}

Calculated model of the BP free molecule belongs to $\boldsymbol{C}_{\boldsymbol{2}}$ point group. It has the view of "right propeller", and this fact is in agreement with the X-ray diffraction analysis data [7]. Full energy of free BP molecule is -576.65 hartrees, the dipole moment is $3.24 D$, the $\mathrm{C}=\mathrm{O}$ bond length is $1.228 \AA$, the dihedral angle between phenyl rings planes is $64.2^{\circ}$, the frequency of the $\mathrm{C}=\mathrm{O}$ stretch is $1658 \mathrm{~cm}^{-1}$.
Full energy of the $5 \mathrm{CB}$ free molecule is -752.14 hartrees, dipole moment is $6.38 \mathrm{D}, \mathrm{C} \equiv \mathrm{N}$ bond length is $1.164 \AA$, the dihedral angle between phenyl rings planes is $38.3^{\circ}$, the frequency of $\mathrm{C} \equiv \mathrm{N}$ stretch is $2226 \mathrm{~cm}^{-1}$.

Calculated model of the $\mathrm{H}_{2} \mathrm{O}$ free molecule belongs to $\boldsymbol{C}_{2 V}$ point group. Full energy of the free water molecule according with the modeling results is -76.42 hartrees, dipole moment is $2.25 \mathrm{D}$, the lengths of the $\mathrm{O}-\mathrm{H}$ bonds is 0.969 $\AA$, $\mathrm{HOH}$ angle is $105.5^{\circ}$, the frequencies of $\mathrm{O}-\mathrm{H}$ stretches are 3668 and $3549 \mathrm{~cm}^{-1}$ respectively.

The model of free $\mathrm{Ti}(\mathrm{OH})_{4}$ molecule belongs to $\mathrm{C}_{S}$. point group. Full energy of this molecule is -1152.95 hartrees according with the results of the modeling. Dipole moment is 1.93 $\mathrm{D}$, Ti-O bond lengths are in the range 1.808$1.813 \AA$, O-H bonds lengths are in the range $0.967-0.968 \AA$ The frequency of the Ti-O stretches is $685 \mathrm{~cm}^{-1}$ and the frequencies of the valence angles changing vibrations ( $\mathrm{Ti}$ atom vertex angles) are 738, 752 and $755 \mathrm{~cm}^{-1}$. The frequencies of O-H stretches are 3625, 3630, 3633 and $3651 \mathrm{~cm}^{-1}$.

The structures of the calculated H-bond complexes models with some signed geometric parameters are showed on the Fig.1.

The modeling of the H-bond complexes gave the following results. Full energy of the $\mathrm{BP}^{\cdots \cdots} \mathrm{H}_{2} \mathrm{O} \mathrm{H}$-bond complex is -653.09 hartrees, dipole moment $4.27 \mathrm{D}$, the $\mathrm{C}=\mathrm{O}$ bond length is $1.234 \AA$. The dihedral angle between phenyl rings planes is $57.8^{\circ}$. The length of the $\mathrm{O}-\mathrm{H}$ bond in hydrogen bridge is $0.978 \AA$, the length of the H-bond $\left(\mathrm{O}^{\cdots \cdots} \mathrm{H}\right)$ is $1.906 \AA$ the hydrogen bond bridge $\left(\mathrm{O}-\mathrm{H}^{\cdots \cdots} \mathrm{O}\right)$ length is $2.884 \AA$, $\mathrm{O}-\mathrm{H}^{\cdots \cdots} \mathrm{O}$ angle value is $167.9^{\circ}$ The frequencies of $\mathrm{C}=\mathrm{O}$ and $\mathrm{O}-\mathrm{H}$ stretches are $1657 \mathrm{~cm}^{-1}$ and $3583 \mathrm{~cm}^{-1}$ respectively.

Full energy of BP ${ }^{\cdots \cdot \cdot H} \mathrm{H}-\mathrm{O}-\mathrm{Ti} \equiv \mathrm{H}-$ bond complex is -1729.62 hartrees, dipole moment 6.21 $\mathrm{D}, \mathrm{C}=\mathrm{O}$ bond length is $1.236 \AA$. The dihedral angle between phenyl rings planes is $59.2^{\circ}-$ its value increased in comparison with the free $\mathrm{BP}$ molecule. The length of the $\mathrm{O}-\mathrm{H}$ bond in hydrogen bond bridge $\left(\mathrm{O}-\mathrm{H}^{\cdots \cdots} \mathrm{O}\right)$ is 0,987 , the length of the hydrogen bond $\left(\mathrm{O}^{\cdots \cdots} \mathrm{H}\right)$ is $1.787 \AA$, hydrogen bond bridge length is $2.774 \AA$, the 

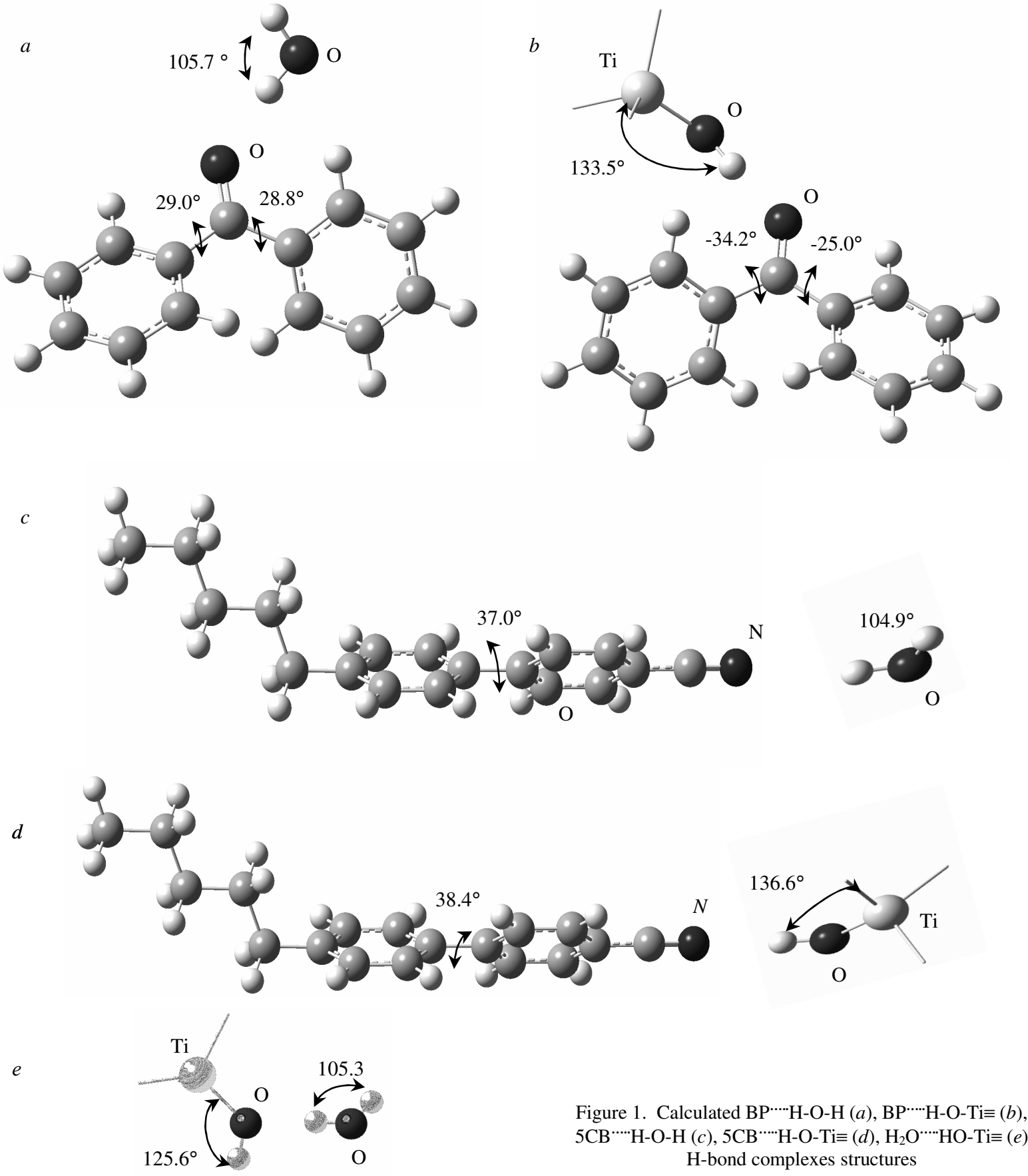

$\mathrm{O}-\mathrm{H}^{\cdots \cdots \cdot} \mathrm{O}$ angle value is $177.5 \AA$, the frequencies of the $\mathrm{C}=\mathrm{O}$ and $\mathrm{O}-\mathrm{H}$ stretches are $1647 \mathrm{~cm}^{-1}$ and $3385 \mathrm{~cm}^{-1}$ respectively.

Full energy of $5 \mathrm{CB} \cdots \mathrm{H}_{2} \mathrm{O}$ H-bond complex is -828.57 hartrees, dipole moment is $9.12 \mathrm{D}$, $\mathrm{C} \equiv \mathrm{N}$ bond length is $1.163 \AA$, the dihedral angle between phenyl rings planes is $38.0^{\circ}$, O-H bond length in hydrogen bridge N $\cdots \cdots \cdot \mathrm{H}-\mathrm{O}$ is $0.975 \AA$, the H-bond $\left(\mathrm{N}^{\cdots \cdots} \mathrm{H}\right)$ length is $2.079 \AA$, the hy- drogen bond bridge length is $3.054 \AA$, the $\mathrm{N} \cdots \cdot \mathrm{H}-\mathrm{O}$ angle value is $176.0^{\circ}$, the frequency of $\mathrm{C} \equiv \mathrm{N}$ stretch is $2233 \mathrm{~cm}^{-1}$.

Full energy of $5 \mathrm{CB} \ldots . . \mathrm{H}-\mathrm{O}-\mathrm{Ti} \equiv \mathrm{H}$-bond complex is 1905.11 hartrees. Dipole moment is $10.95 \mathrm{D}$. $\mathrm{C} \equiv \mathrm{N}$ bond length is $1,162 \AA$, the dihedral angle between phenyl rings planes is $38.4^{\circ}$, $\mathrm{O}-\mathrm{H}$ bond length in hydrogen bridge N.....H-O is $0.981 \AA$, the $\mathrm{H}$-bond $(\mathrm{N} \ldots . . \mathrm{H})$ length is 
$1.924 \AA$, the hydrogen bond bridge length is $2.905 \AA$, the N.....H-O angle value is $178.7^{\circ}$, the frequencies of the $\mathrm{C}=\mathrm{O}$ and $\mathrm{O}-\mathrm{H}$ stretches are $2237 \mathrm{~cm}^{-1}$ and $3420 \mathrm{~cm}^{-1}$ respectively.

Full energy of $\mathrm{H}_{2} \mathrm{O} \cdots \cdot \mathrm{H}-\mathrm{O}-\mathrm{Ti} \equiv \mathrm{H}$-bond complex is 1229.39 hartrees. Dipole moment is 4.18 D, O-H bonds lengths in water are $0.978 \AA$ and $0.968 \AA$. O-H bond length that is closest to the hydrogen bond in $\mathrm{H}-\mathrm{O}-\mathrm{Ti} \equiv$ fragment is $0.970 \AA$. Ti-O bond length is $1.838 \AA$. The length of the $\mathrm{H}^{\cdots \cdots} \mathrm{O}$. hydrogen bond is $1.904 \AA$. The length of the hydrogen bond bridge $\left(\mathrm{O}-\mathrm{H}^{\cdots \cdots} \mathrm{O}\right)$ is $2.874 \AA$. The $\mathrm{O}-\mathrm{H}^{\cdots \cdots} \mathrm{O}$ angle is $174.9^{\circ}$. The frequency of closest to $\mathrm{H}-$ bond Ti-O stretch is $670 \mathrm{~cm}^{-1}$, the frequencies of the $\mathrm{Ti}$ atom vertex angles vibrations are 734, 756 and $766 \mathrm{~cm}^{-1}$. The frequency of the $\mathrm{O}-\mathrm{H}$ stretch in the $\mathrm{O}-\mathrm{H}^{\cdots \cdots} \mathrm{O} \mathrm{H}$-bond bridge $(\mathrm{O}-\mathrm{H}$ from water and $\mathrm{O}$ from $\mathrm{H}-\mathrm{O}-\mathrm{Ti} \equiv$ fragment) is $3548 \mathrm{~cm}^{-1}$.

In the Table are given the main calculated parameters of the considered molecular systems: the lengths of the $\mathrm{O}-\mathrm{H}, \mathrm{C}=\mathrm{O}$ and $\mathrm{C} \equiv \mathrm{N}$ bonds, the frequencies of their stretches, intensities in calculated IR spectra, the shifts of the frequencies at the H-bond complex formation and estimated H-bond energies. The analysis of the data from the table 1 and of the modeling results represented in the paper allows making a conclusion about the influence of the H-bond complexes formation on the structures and spectra of $\mathrm{BP}$ and 5CB molecules. It also allows answering on the main question about the structure forming role of the $\mathrm{H}$-bond in the forming of the near surface layers of the $\mathrm{TiO}_{2}$ nano crystalline particles.

In $\mathrm{BP}-\mathrm{TiO}_{2}$ bicomponent mixture in near surface layer are forming the $\mathrm{H}$-bond complexes $\mathrm{BP} \cdots \cdot \mathrm{H}-\mathrm{O}-\mathrm{H}, \mathrm{H}_{2} \mathrm{O} \cdots \cdot \mathrm{H}-\mathrm{O}-\mathrm{Ti} \equiv, \mathrm{BP}{ }^{\cdots \cdots} \mathrm{H}-\mathrm{O}-\mathrm{Ti} \equiv$ and $\mathrm{H}$-bond complexes of the water. According with the modeling results at the $\mathrm{BP}^{\cdots \cdots} \mathrm{H}_{2} \mathrm{O} \mathrm{H}$-bond complex formation the length of $\mathrm{C}=\mathrm{O}$ bond is increasing by $0.006 \AA$ and the frequency of the $\mathrm{C}=\mathrm{O}$ stretch is decreasing by $1 \mathrm{~cm}^{-1}$. Intensity of this vibration is increased 1.23 times. The length of $\mathrm{O}-\mathrm{H}$ bond of water is increasing by $0.009 \AA$ and the frequency of its stretch is decreasing by $85 \mathrm{~cm}^{-1}$ and the IR intensity of this vibration is increased ten times approximately. The energy of $\mathrm{H}$-bond $\Delta \mathrm{H}$ is $2.01 \mathrm{kcal} / \mathrm{moles}$.
The influence of H-bond on the dynamics of adsorbent and ${ }^{*} \mathrm{H}-\mathrm{O}-\mathrm{Ti} \equiv$ molecular system

\begin{tabular}{|c|c|c|c|c|c|}
\hline Object & $\begin{array}{c}\mathrm{v}, \\
\mathrm{cm}^{-1}\end{array}$ & $\begin{array}{c}I_{I R}, \\
\mathrm{~km} / \text { mole }\end{array}$ & $\begin{array}{c}\text { Assign- } \\
\text { ment }\end{array}$ & $\begin{array}{l}\Delta \mathrm{v}^{*}, \\
\mathrm{~cm}^{-1}\end{array}$ & $\begin{array}{c}\Delta H, \\
\text { kcal } / \text { mole }\end{array}$ \\
\hline $\mathrm{BP}$ & 1658 & 188.9 & $\mathrm{Q}(\mathrm{C}=\mathrm{O})$ & - & - \\
\hline \multirow{2}{*}{$\mathrm{BP}^{\cdots \cdots} \mathrm{H}_{2} \mathrm{O}$} & 1657 & 231.6 & $\mathrm{Q}(\mathrm{C}=\mathrm{O})$ & 1 & - \\
\hline & 3583 & 510.7 & $\mathrm{Q}(\mathrm{O}-\mathrm{H})$ & 85 & 2.01 \\
\hline \multirow{2}{*}{$\mathrm{BP}^{\cdots \cdots} \mathrm{H}-\mathrm{O}-\mathrm{Ti} \equiv$} & 1647 & 314.2 & $\mathrm{Q}(\mathrm{C}=\mathrm{O})$ & $11-$ & - \\
\hline & 3385 & 2149 & $\mathrm{Q}(\mathrm{O}-\mathrm{H})$ & 266 & 4.51 \\
\hline $5 \mathrm{CB}$ & 2226 & 90.6 & $\mathrm{Q}(\mathrm{C} \equiv \mathrm{N})$ & - & - \\
\hline \multirow{2}{*}{$5 \mathrm{CB} \cdots \cdots \cdot \mathrm{H}_{2} \mathrm{O}$} & 2233 & 173.7 & $\mathrm{Q}(\mathrm{C} \equiv \mathrm{N})$ & - & - \\
\hline & 3518 & 510.7 & $\mathrm{Q}(\mathrm{O}-\mathrm{H})$ & 150 & 3.15 \\
\hline \multirow{2}{*}{$5 \mathrm{CB}{ }^{\cdots \cdots} \mathrm{H}-\mathrm{O}-\mathrm{Ti} \equiv$} & 2237 & 225.1 & $\mathrm{Q}(\mathrm{C} \equiv \mathrm{N})$ & - & - \\
\hline & 3420 & 2678.7 & $\mathrm{Q}(\mathrm{O}-\mathrm{H})$ & 231 & 4.15 \\
\hline $\mathrm{H}_{2} \mathrm{O}$ & 3668 & 52.9 & $\mathrm{Q}(\mathrm{O}-\mathrm{H})$ & - & - \\
\hline $\mathrm{Ti}-(\mathrm{OH})_{4}$ & 3651 & 148.7 & $\mathrm{Q}(\mathrm{O}-\mathrm{H})$ & - & - \\
\hline $\mathrm{H}_{2} \mathrm{O} \cdots \cdot \mathrm{H}-\mathrm{O}-\mathrm{Ti} \equiv$ & 3548 & 442.2 & $\mathrm{Q}(\mathrm{O}-\mathrm{H})$ & 119 & 2.67 \\
\hline
\end{tabular}

${ }^{*} \Delta v$ was determined as a difference between of maximal calculated frequency of $\mathrm{O}-\mathrm{H}$ stretch in the free molecule and frequency of the $\mathrm{O}-\mathrm{H}$ stretch in corresponding $\mathrm{H}$-bond complex.

At the $\mathrm{H}_{2} \mathrm{O} \cdots \cdots \cdot \mathrm{H}-\mathrm{O}-\mathrm{Ti} \equiv \mathrm{H}$-bond complex formation the $\mathrm{O}-\mathrm{H}$ bond of hydroxyl is increasing slightly (by $0.002 \AA$ ) and the $\mathrm{O}-\mathrm{H}$ bond of water increases by $0.009 \AA$. The Ti-O bond length is increased by $0.03 \AA$. The frequencies of the $\mathrm{O}-\mathrm{H}$ stretches of water in the hydrogen bond bridge $\mathrm{O} \cdots \cdot \mathrm{H}-\mathrm{O}$ is decreased by $119 \mathrm{~cm}^{-1}$. The energy of $\mathrm{H}$-bond $\Delta \mathrm{H}$ is $2.67 \mathrm{kcal} / \mathrm{moles}$.

At the $\mathrm{BP} \cdots \cdot \mathrm{H}-\mathrm{O}-\mathrm{Ti} \equiv \mathrm{H}$-bond complex formation the $\mathrm{C}=\mathrm{O}$ bond is increasing by $0.008 \AA$ the frequency of its stretch is decreasing by $11 \mathrm{~cm}^{-1}$ and the IR intensity of this stretch is 1.66 times increased. The $\mathrm{O}-\mathrm{H}$ bond length of the hydroxyl is increased by $0.02 \AA$, the frequency of its stretch is decreased by $266 \mathrm{~cm}^{-1}$ and the IR intensity of the stretch is approximately ten times increased. The energy of $\mathrm{H}$-bond $\Delta \mathrm{H}$ is $4.51 \mathrm{kcal} / \mathrm{moles}$. It is computed using the difference between the maximal frequency of the $\mathrm{O}-\mathrm{H}$ stretches in $\mathrm{Ti}(\mathrm{OH})_{4}$ free molecule and the frequency of $\mathrm{O}-\mathrm{H}$ stretch of the hydroxyl in the $\mathrm{H}$-bond bridge $\left(\mathrm{O}-\mathrm{H}^{\cdots \cdots} \mathrm{O}\right)$ in BP $\cdots \cdot \mathrm{H}-\mathrm{O}-\mathrm{Ti} \equiv \mathrm{H}-$ bond complex.

In the $5 \mathrm{CB}-\mathrm{TiO}_{2}$ bicomponent mixture in near surface layer of the $\mathrm{TiO}_{2}$ nano crystalline

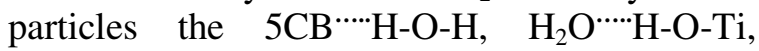
$5 \mathrm{CB} \cdots \cdot \mathrm{H}-\mathrm{O}-\mathrm{Ti} \equiv$ and water $\mathrm{H}$-bond complexes are formed. According to the results of the mod- 
eling for the $5 \mathrm{CB}^{\cdots \cdots} \mathrm{H}-\mathrm{O}-\mathrm{H}$ H-bond complex model the following results obtained. The $\mathrm{O}-\mathrm{H}$ bond length is increased by $0.006 \AA$, the frequency of its stretch is decreasing by $150 \mathrm{~cm}^{-1}$. The energy of the $\mathrm{H}$-bond is $3.15 \mathrm{kcal} /$ moles. The $\mathrm{C} \equiv \mathrm{N}$ bond length is decreased by $0.001 \AA$, the frequency of its stretch is increased by $7 \mathrm{~cm}^{-1}$.

A similar situation is taking place at the $5 \mathrm{CB} \cdots \mathrm{H}-\mathrm{O}-\mathrm{Ti} \equiv \mathrm{H}$-bond complex formation. The $\mathrm{C} \equiv \mathrm{N}$ bond length is decreasing by $0.002 \AA, \mathrm{O}-\mathrm{H}$ bond length is increasing by $0.014 \AA$ The frequency of the $\mathrm{C} \equiv \mathrm{N}$ stretch increases by $11 \mathrm{~cm}^{-1}$, and the frequency of $\mathrm{O}-\mathrm{H}$ stretch is decreasing by $231 \mathrm{~cm}^{-1}$. The H-bond energy is $4.15 \mathrm{kcal} /$ /moles. The peculiarity of the complex formation process in $5 \mathrm{CB}-\mathrm{TiO}_{2}$ system is the frequency increasing of the $\mathrm{C} \equiv \mathrm{N}$ stretch and decreasing of the $\mathrm{C} \equiv \mathrm{N}$ bond length.
Results of the modeling, and calculated IR spectra particularly are in good agreement with the experimental data (Figs. 2, 3). The derivation of the contours of the experimental bands corresponding to the $\mathrm{O}-\mathrm{H}, \mathrm{C}=\mathrm{O}$, and $\mathrm{C} \equiv \mathrm{N}$ stretches can be easily explained on the basis of the IR spectra calculations. In $3200-3600 \mathrm{~cm}^{-1}$ region of the $\mathrm{BP}-\mathrm{TiO}_{2}$ mixture IR spectra the $\mathrm{O}-\mathrm{H}$ stretches of the $\mathrm{BP} \cdots \cdot \mathrm{H}-\mathrm{O}-\mathrm{H}, \mathrm{H}_{2} \mathrm{O} \cdots \cdot \mathrm{H}-\mathrm{O}-\mathrm{Ti} \equiv$,

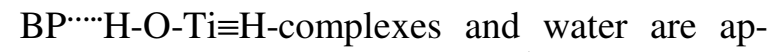
peared. In the $1640-1650 \mathrm{~cm}^{-1}$ region a carbonyl group stretches of $\mathrm{BP}$ and of its $\mathrm{H}$-bond complexes (BP $\cdots \cdot \mathrm{H}-\mathrm{O}-\mathrm{Ti} \equiv, \mathrm{BP} \cdots \cdot \mathrm{H}-\mathrm{O}-\mathrm{H}$, see Fig. 2) are appeared. In the $2215-2245 \mathrm{~cm}^{-1}$ region of the $5 \mathrm{CB}-\mathrm{TiO}_{2}$ heterogenic mixture IR spectrum the cyano group valence stretches of the $5 \mathrm{CB}$ and of its $\mathrm{H}$-bond complexes $\left(5 \mathrm{CB}{ }^{\cdots \cdots} \mathrm{H}\right.$ $-\mathrm{O}-\mathrm{H}, 5 \mathrm{CB} \cdots \cdot \mathrm{H}-\mathrm{O}-\mathrm{Ti} \equiv$, see Fig. 3) are appeared.
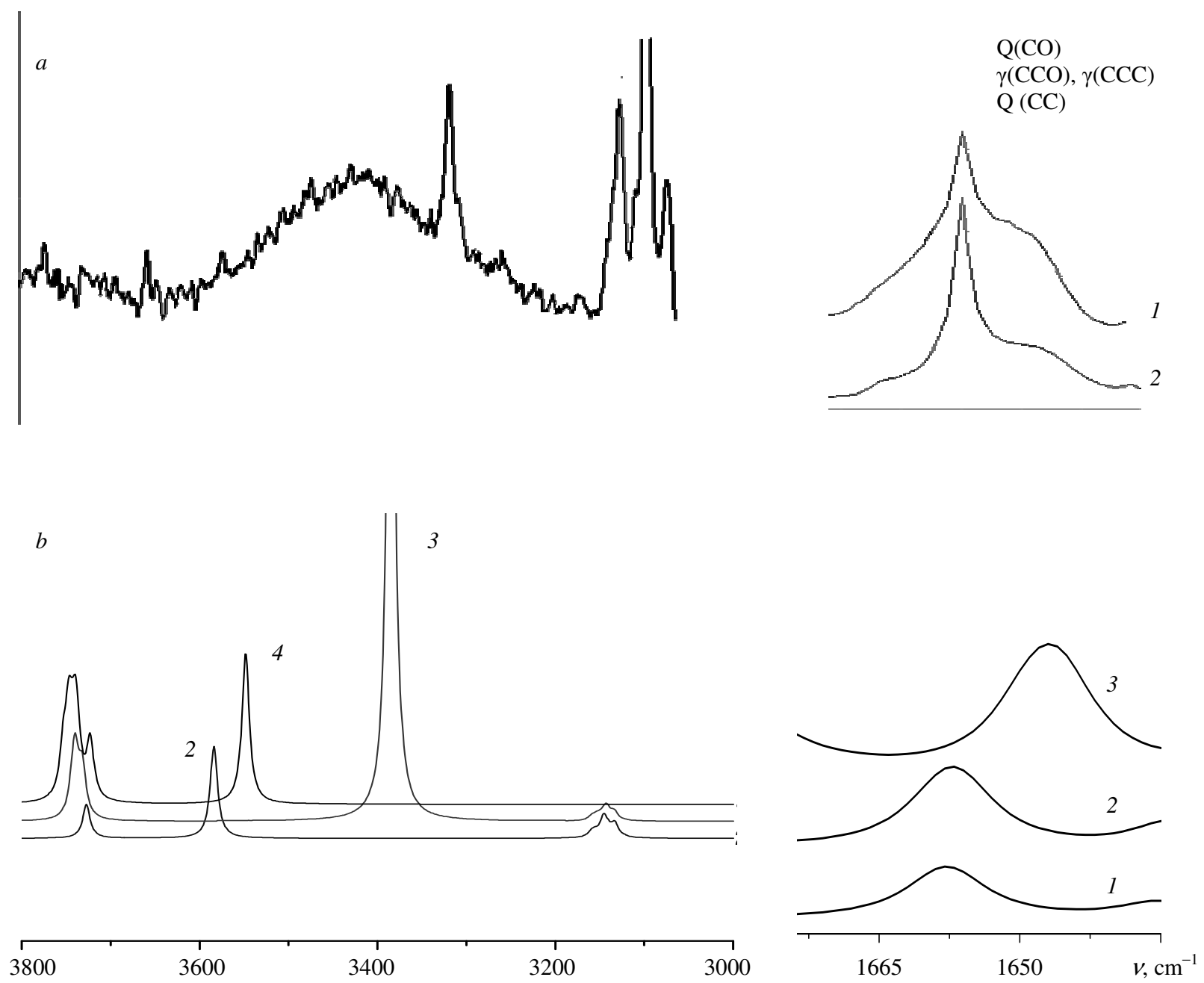

Figure 2. A comparison of the experimental IR spectrum $(a)$ of $\mathrm{BP}_{-} \mathrm{TiO}_{2}$ mixture, $\mathrm{BP}(2)$ and calculated $(b)$ IR spectra of $\mathrm{BP}(1)$, BP $\cdots \cdot \cdot \mathrm{H}-\mathrm{O}-\mathrm{H}(2)$ and $\mathrm{BP}+\cdots \cdot \mathrm{H}-\mathrm{O}-\mathrm{Ti} \equiv(3) \mathrm{H}_{2} \mathrm{O} \cdots \cdot \mathrm{HO}-\mathrm{Ti} \equiv(4)$ 


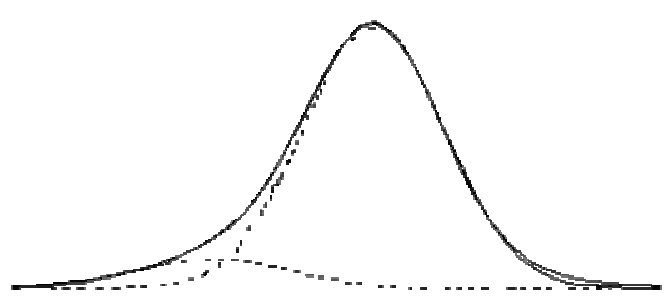

$a$

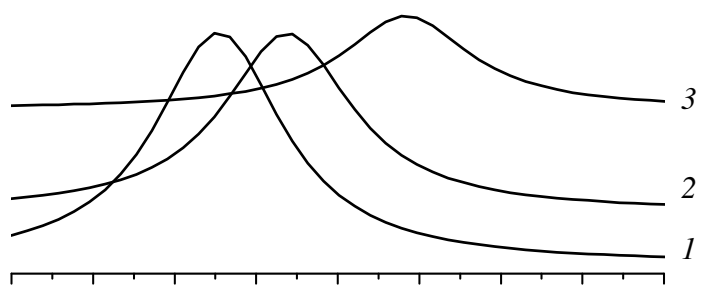

$b$

Figure 3. Comparison of the experimental IR spectra of $5 \mathrm{CB}-\mathrm{TiO}_{2}$ mixture $(a)$ with the calculated spectra $(b)$ of $5 \mathrm{CB} \cdots \cdot \mathrm{H}-\mathrm{O}-\mathrm{Ti} \equiv(1), 5 \mathrm{CB} \cdots \cdot \mathrm{H}-\mathrm{O}-\mathrm{H} \equiv(2)$ and $5 \mathrm{CB}(3)$

This becomes obvious after the decomposition of the contour of experimental curve into two contours, one of which has small intensity and is blue-shifted. This contour matches to the H-bond complexes vibrations.

\section{CONCLUSION}

The analysis of the measured IR spectra of the $\mathrm{BP}-\mathrm{TiO}_{2}$ and $5 \mathrm{CB}-\mathrm{TiO}_{2}$ heterogenic nanosystems and of the free water, $\mathrm{BP}, 5 \mathrm{CB}$, and $\mathrm{Ti}(\mathrm{OH})_{4}$ molecules together with the analysis of

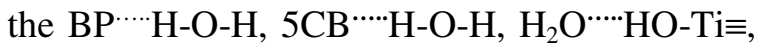

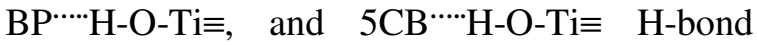
complexes modeling results allows to make a conclusion, that the basic mechanism of the intermolecular interactions in the near surface layers of the $\mathrm{TiO}_{2}$ nano crystalline particles is the hydrogen bond. It is determining the structure and the composition of the near surface layer. The hydrogen bond is revealed due to the representative wide band in the $3200-3600 \mathrm{~cm}^{-1}$ region. This band corresponds to the hydroxyl groups of H-bond complexes stretches. Hydrogen bond is also transforming the IR spectra of the $\mathrm{BP}$ and $5 \mathrm{CB}$ probe molecules in the regions of the appearance of the $\mathrm{C}=\mathrm{O}$ and $\mathrm{C} \equiv \mathrm{N}$ bonds stretches. The analysis of the corresponding bands in IR spectra allowed the authors to found the representative peculiarities of the $\mathrm{H}$-bond complexes formation processes in the $\mathrm{BP}-\mathrm{TiO}_{2}$ and $5 \mathrm{CB}-\mathrm{TiO}_{2}$ systems. One of these peculiarities is the effect of the frequency increasing of the $\mathrm{C} \equiv \mathrm{N}$ stretch and the decreasing of the $\mathrm{C} \equiv \mathrm{N}$ bond length in $5 \mathrm{CB}-\mathrm{TiO}_{2}$ system. The H-bonds in the H-bond complexes had estimated as $\mathrm{H}$-bonds with medium strength with the energies values in range $2.1-4.51 \mathrm{kcal} /$ moles. Measured IR spectra of the $\mathrm{BP}-\mathrm{TiO}_{2}$ and $5 \mathrm{CB}-\mathrm{TiO}_{2}$ mixtures are the superposition of the free $\mathrm{BP}, 5 \mathrm{CB}$ and $\mathrm{TiO}_{2}$ molecules IR spectra and of the IR spectra of the $\mathrm{H}$-bond complexes forming in near surface layer of the $\mathrm{TiO}_{2}$ nano crystalline particles.

\section{References}

1. Bezrodna T., Mel'nik V., Nelipovich K. Spectroscopic study of heterogeneous nanocomposition systems based on benzophenone // J. Mol. Struct. 2001. V.596. P.55-60.

2. Bezrodna T., Gavrilko T., Puchkovska G., Shimanovska V. Spectroscopic study of $\mathrm{TiO}_{2}$ (rutile)-benzophenone heterogeneous systems // J. Mol. Struct. 2002. V.1-3. P.315-324.

3. Bezrodna T., Puchkovska G., Shimanovska V. IR-analysis of $\mathrm{H}$-bonded $\mathrm{H}_{2} \mathrm{O}$ on the pure $\mathrm{TiO}_{2}$ surface // J. Mol. Struct. 2004. V.700. P.175-181.

4. Frisch J., Trucks G.W., Schlegel H.B. Gaussian03, Revision B.03; Pittsburgh PA. Gaussian Inc., 2003. 302 p.

5. Брезин К.В., КривохижинаТ.В., Нечаев В.В. Применение метода линейного масштабирования частот в расчетах нормальных колебаний многоатомных молекул // Опт. и спектроск. 2003. Т.94. С.398-401.

6. Иогансен А.В. ИК спектроскопия и определение энергии водородной связи // Водородная связь. М., 1981. С.112-155.

7. Вул Е.Б., Лобанова Г.М. Предварительная модель структуры бензофенона // Кристаллография. 1967. Т.12. С.411-415. 